\title{
Human Rights for All Is Better than Citizenship Rights for Some
}

\author{
Daniel Kanstroom
}

This is an exceptionally rich and challenging discussion in which I am honoured to participate, though space limitations will inspire brevity. Audrey Macklin's essay reaches two major conclusions with which I heartily agree:

1. Citizenship-stripping weakens the concept of citizenship;

2. It is of highly-questionable efficacy and legitimacy as punishment; ${ }^{1}$

Despite my deep agreement with Macklin about the dangers of denationalisation trends in the UK, Canada, and elsewhere, I am not convinced that she has chosen the best way to counter them. In brief, I fear that Macklin may have missed some of the forest for the trees.

My view of the forest is this: Denationalisation should be situated against a broader backdrop in which pervasive rights deprivations against noncitizens - and even such extraterritorial rights deprivations against citizens as drone strikes - are central components. Macklin points us in this direction when she distinguishes the aspirational safe harbour of citizenship from a functional methodology:

But my point is not to propose a metric capable of measuring the quantitative, qualitative, experiential, emotional, personal, familial, cultural, social, financial, linguistic and political impacts of exile on any individual, in order that some state official could determine precisely when citizenship revocation inflicts an appropriate versus excessive degree of punishment.

I fully support Macklin's desire to enhance 'the security that distinguishes legal citizenship.' I worry, though, about what certain approaches to such security might mean for 'other statuses that define the relationship between state and individual.' The challenge is to protect citizenship rights without relegating those 'other statuses' unduly tenuous and marginal.

1 Though I agree with Kay Hailbronner that legitimacy is an elusive concept in need of further definition. I believe that one can do this relatively easily in this context. 
Put simply, I suggest that the best way to do this is less (formally) citizenship-centred and more (functionally) rights-centred. By 'rights-centred,' I mean, essentially, a critical examination of state practices (including the government's intentions and justifications, and the practices' mechanisms, and effects) measured against the norms of a fully-developed human rights protection system. ${ }^{2}$ More specifically, the important legal and policy questions raised by Macklin may be best answered by viewing denationalisation along a continuum of state practices that use citizenship status and territorial formalism to achieve policy goals with weakened (and in some cases no) rule of law encumbrances. This is one of the great human rights legal challenges of our times. It must be engaged fully - in all of its manifestations in order to be properly understood and effectively engaged.

Macklin rightly notes that, '...citizenship revocation is best understood as a technique for extending the functionality of immigration law in counterterrorism.' Moreover, '[s]ince 2001, states have turned to deportation to resolve threats to national security by displacing the embodied threat to the country of nationality.' However, the deep significance of these insights may be lost by too formalistic and narrow an examination of the particular practice of denationalisation. A basic reason for this is the powerful attraction symbolic and practical - of citizenship as a safe harbour. That, in and of itself, is unobjectionable. But it risks denigration of the rights claims of noncitizens. Let me emphasize that I do not think that Macklin intends this at all. Still, her method may take us there.

Here is an example. Macklin writes, 'Banishment fits the crime of disloyalty the way capital punishment fits the crime of murder.' This works for me passably well as analogy (though, of course, the 'crime' of disloyalty is a much more complex proposition than murder). But the analogy prompts a question: How does banishment (of citizens) differ from what I have termed 'post-entry social control deportation,' which in the U.S. has resulted in lifetime exclusion of many thousands of long-term legal residents from their families and communities due to minor criminal offenses? ${ }^{3}$ Does their lack of citizenship status render the death penalty analogy less apt? In another passage, Macklin correctly worries about 'arbitrary and prejudicial abuse of a discretionary power.' What do we make of the fact that such abuses are

2 See e.g., A and others v Secretary of State for the Home Department [2004] UKHL 56, available at http://www.bailii.org/uk/cases/UKHL/2004/56.html

3 See e.g., Kanstroom, D. (2007), Deportation Nation: Outsiders in American History. Cambridge: Harvard University Press; Kanstroom, D. (2012), Aftermath: Deportation Law and New American Diaspora. New York: Oxford University Press. 
rare against citizens and troublingly common against noncitizens? Macklin is thus right, but perhaps insufficiently expansive when she asserts that the particular practice of denationalisation 'is exile.' Is denationalisation categorically different from expulsion and removal of long-term legal residents because, as Macklin argues, it 'extinguishes a singular right of citizenship, namely the right to enter and to remain'? This seems formalistic and perhaps a bit circular. A fuller exploration might consider the actual effects of deportation and denationalisation on people of various statuses, various levels of assimilation, and various fears of harm. This would help explain why the 'right' to enter and remain is so crucial to protect against disproportionate or arbitrary state action against all people.

My main concern is about the potential implications of Macklin's methodology. The formalistic reification of citizenship may justify the relegation of noncitizens to a nether world of inferior balancing tests. ${ }^{4}$ This is especially the case if that reification is connected to an implicitly exclusive set of rights claims to enter and remain. Noncitizens have such rights, too, at least under certain circumstances. Insufficient attention to such rights - though they are concededly still works-in-progress - is especially dangerous where the rights claims at issue include the right to life, to proportional punishment, to family unity, against arbitrary detention, and to procedural fairness.

Let us also consider the etiology and evolution of denationalisation. Harsh expulsion and exclusion practices against noncitizens can provide a conceptual matrix that facilitates similar practices against citizens. As Thomas Jefferson - writing to oppose the Federalists' Alien Friends Act, Alien Enemies Act, and Sedition Act - warned in 1798: 'The friendless alien has indeed been selected as the safest subject of a first experiment, but the citizen will soon follow... ${ }^{5}$ The best response to this concern, however, is not a regime of exclusive protections only for citizens. Rather, we should strengthen reasonable (procedural and substantive) human rights protections for all people, regardless of status or location. I expect that Macklin would not strongly disagree with this. Still, insufficient attention to such experiments against noncitizens have had metastatic tendencies in the past.

4 I suppose that the opposite might also be true in certain circumstances. Rights gains won by citizens could form models that protect long term residents, albeit in depreciated form. But this pathway works best if citizenship is viewed on a continuum.

5 The Kentucky Resolution, Documents of American History 181 (Henry Steele Commager ed., 6th ed. 1958). 
Denationalisation should not be viewed as an anomalous practice that requires a unique normative critique grounded on a strong, formalistic conception of citizenship as the (supposed) Arendtian 'right to have rights.' Rather, it should be viewed as the apotheosis of an evolving array of exclusion and removal practices, as well as the episodic search by governments for what some termed Guantánamo Bay: 'a legal black hole. ${ }^{6}$ A more capacious analysis would thus not only critique the British, 'conducive to the public good' standard as relegating citizens to the status of permanent residents. It would equally question the standard's legitimacy and propriety for the latter group. ${ }^{7}$ (Indeed, its attempted application to citizens might be ironically salutary, as political opposition will be more readily mobilised if it is practiced widely.)

Easy denationalisation deserves normative and practical critique, to be sure. As Rainer Bauböck properly highlights, citizenship is (and should be) 'sticky' and thus denationalisation must be justified as punishment. This practice is ill advised, problematic, and especially difficult to justify in liberal democracies for the reasons he highlights. However, critique should be primarily grounded in a broader set of human rights norms that apply whenever a state seeks to use its power disproportionately or arbitrarily against anyone anywhere. This is especially important for those who are strongly assimilated, who would be rendered juridically or functionally stateless or who would face severe harm, persecution, or torture.

In a similar vein, I would not recapitulate the rather formalistic and ultimately sterile debate between a 'right' and a 'privilege,' nor rely too readily on Justice Earl Warren's implicit references to Hannah Arendt. When Warren asserted that citizenship is 'the right to have rights,' he was tactically using this phrase to justify a particular position in a dissent in a 1958 case. ${ }^{8}$ The case involved a U.S. citizen (by birth) who had lived most of his life in Texas

6 See Hamdan v. Rumsfeld, 548 U.S. 557 (2006) (concluding: 'We have assumed ... that Hamdan is a dangerous individual whose beliefs, if acted upon, would cause great harm and even death to innocent civilians, and who would act upon those beliefs if given the opportunity. ... But in undertaking to try Hamdan and subject him to criminal punishment, the Executive is bound to comply with the Rule of Law that prevails in this jurisdiction.') See also, Steyn, J. (2004), 'Guantanamo Bay: The Legal Black Hole', The International and Comparative Law Quarterly 53 (1): 1-15.

7 By which I mean conformity to the best understanding of the 'rule of law' in all its aspects, including procedural and substantive protections of basic rights.

$8 \quad$ Perez v. Brownell, 356 U.S. 44 (1958). 
and had voted there in $1946 .{ }^{9}$ The court narrowly upheld the denationalisation (also called 'expatriation'). Justice Warren wrote a somewhat rambling dissent built around the (unattributed) reference to Arendt. ${ }^{10} \mathrm{He}$ concluded with two apparently contradictory propositions. The first was seemingly absolute, if a bit puzzling: 'The Government is without power to take citizenship away from a native-born or lawfully naturalized American. ${ }^{11}$ The second conclusion focused on the intention of the citizen: 'The citizen may elect to renounce his citizenship, and under some circumstances he may be found to have abandoned his status by voluntarily performing acts that compromise his undivided allegiance to his country.' Thus, even Justice Warren accepted that certain conduct could justify expatriation, so long as the conduct was voluntary. ${ }^{12}$ But this fits poorly with the absolutist reading of the 'right to have rights.' Who would voluntarily relinquish the right to have all rights?

Later U.S. cases elaborated on the criterion of voluntariness, ultimately elevating it to the dominant principle. ${ }^{13}$ However, as Justice Harlan once noted, the historical evidence limiting government power to voluntary

9 The 1940 law at issue had been passed largely in response (ironically for our purposes) to voting by American citizens in a 1935 plebiscite relating to Hitler's annexation of the Saar region. As one member of congress put it. The legislation would 'relieve this country of the responsibility of those who reside in foreign lands and only claim citizenship when it serves their purposes.' Id. at 55 (in opinion of Justice Frankfurter).

10 (joined by Justices Douglas and Black)

11 Puzzling because the latter practice (denaturalisation) was well accepted in a wide variety of situations, such as where naturalisation had been illegally procured. The term, 'lawfully,' thus meant that one could not be denaturalised absent a finding that the naturalisation (viewed retrospectively, had been in some way unlawful).

12 Cf. Trop v. Dulles, 356 U.S. 86 (1958) (in which Justice Warren, writing for a plurality, found denationalisation of a military deserter to be invalid for similar reasons, and also invalid as cruel and unusual punishment, because it resulted in 'the total destruction of an individual's status in organized society.')

13 See e.g., Aforyim v. Rusk, 387 U.S. 253 (1967) ('First we reject the idea... that...Congress has any general power, express or implied, to take away an American citizen's citizenship without his assent.'); Vance v. Terrazas, 444 U.S. 252 (1980) ('[T]rier of fact must in the end conclude that the citizen not only voluntarily committed the expatriating act prescribed in the statute, but also intended to relinquish his citizenship.' Proof may be by a 'preponderance of the evidence' standard.) See also, Pub.L.99-653 (1986) (adopting this approach). 
expatriation was questionable, to say the least. ${ }^{14}$ Harlan highlighted a more functional, less formalistic defence of citizenship: 'Once obtained, citizenship is of course protected from arbitrary withdrawal by the constraints placed around Congress' powers by the Constitution....' This model seems to dovetail with Peter Schuck's proposal in this debate. ${ }^{15}$ It has the powerful virtue of situating denationalisation within the rubric of well-accepted protections of the rule of law.

Finally, one should also note something obvious but worth highlighting: Hannah Arendt's position was not that citizenship should be the 'right to have rights.' Rather, as she expressly put it: 'The Rights of Man, supposedly inalienable, proved to be unenforceable... whenever people appeared who were no longer citizens of any sovereign state. ${ }^{16}$ Her concerns were practical: Such people lacked any real protection. When she explored the subject substantively her argument was much more nuanced: ' ...recent attempts to frame a new bill of human rights, which seem to have demonstrated that no one seems able to define with any assurance what these general human rights, as distinguished from the rights of citizen, really are. ${ }^{17}$ But Arendt published The Origins of Totalitarianism in 1951. It hardly needs to be said that - despite its evident challenges and deficiencies - the corpus of human

14 Senator Howard, who had sponsored the Citizenship Clause of the Fourteenth Amendment, had conceded that citizenship could be 'forfeited' due to 'the commission of some crime.'

15 It should also be noted that US law has long provide for such denationalisation for a wide variety of actions, including: 'committing any act of treason against, or attempting by force to overthrow, or bearing arms against, the United States, violating or conspiring to violate any of the provisions of section 2383 of title 18 , United States Code, or willfully performing any act in violation of section 2385 of title 18, United States Code, or violating section 2384 of said title by engaging in a conspiracy to overthrow, put down, or to destroy by force the Government of the United States, or to levy war against them, if and when he is convicted thereof by a court martial or by a court of competent jurisdiction.' Immigration and Nationality Act Sec. 349. [8 U.S.C. 1481].

The operative standard, as noted, is the following:

'A person who is a national of the United States whether by birth or naturalisation, shall lose his nationality by voluntarily performing any of the following acts with the intention of relinquishing United States nationality- ...' Kay Hailbronner correctly highlights the prevalence of such standards elsewhere though I am less optimistic than he about the ability of states to define terrorism with sufficient precision to justify denationalisation.

16 Arendt, H. (1966), The Origins of Totalitarianism. New York: Harcourt, Brace \& World, Inc., 293.

17 Indeed, Arendt herself defined the 'right to have rights' not as formal citizenship status as such, but as the right 'to live in a framework where one is judged by one's actions and opinions...' She distinguished this from the related 'right to belong to some kind of organized community.' (Ibid: 296-7) 
rights protections is today more specific, more robust, and more widely enforced than was the case during the times she considered.

Arendt also poignantly described the 'calamity of the rightless' as 'that they no longer belong to any community whatsoever.' The main reason this was a calamity was that 'no law exists for them.' ${ }^{18}$ The best way to avoid such calamities is not only to strengthen citizenship protections. That may well have the perverse consequences of, on the one hand, rendering citizenship ever harder to achieve, and on the other, relegating noncitizens to an increasingly rightless realm. We must do the harder, more basic work of defining and instantiating meaningful human rights protections for all people, regardless of status, or location. Focusing too specifically on the problem of deprivation of citizenship must not blind us 'to the numerous small and not so small evils with which the road to hell is paved.' ${ }^{19}$

Open Access This chapter is licensed under the terms of the Creative Commons Attribution 4.0 International License (http://creativecommons.org/licenses/by/4.0/), which permits use, sharing, adaptation, distribution and reproduction in any medium or format, as long as you give appropriate credit to the original author(s) and the source, provide a link to the Creative Commons license and indicate if changes were made.

The images or other third party material in this chapter are included in the chapter's Creative Commons license, unless indicated otherwise in a credit line to the material. If material is not included in the chapter's Creative Commons license and your intended use is not permitted by statutory regulation or exceeds the permitted use, you will need to obtain permission directly from the copyright holder.

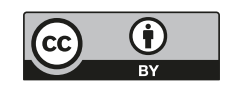

18 Ibid: 295.

19 Arendt, H. (1994), Essays in Understanding, 1930-1954: Formation, Exile, and Totalitarianism. New York: Schocken Books, 271. 